\title{
MANUALINĖS TERAPIJOS IR PRATIMŲ POVEIKIS NUGAROS SKAUSMUI BEI FUNKCINEI BÜKLEI
}

\author{
Šarūnas Zabiela ${ }^{1}$, Rolandas Kesminas ${ }^{1}$, Viljamas Sipavičius ${ }^{2}$ \\ Lietuvos sporto universitetas ${ }^{1}$ \\ Lietuvos sveikatos mokslu universitetas ${ }^{2}$
}

\section{SANTRAUKA}

Tyrimo pagrindimas. Apie $85 \%$ populiacijos skundžiasi nespecifiniu nugaros apatinès dalies skausmu. Nustatyta, kad stuburo stabilizavimo pratimai pagerina juosmens giliujų raumenų funkciją ir sumažina nugaros skausmą, o stuburo mobilizacija sumažina neigalumą ir skausmą gydant lètinị nugaros skausmą. Visgi nėra pakankamai tyrimų, kuriuose būtų įrodytas didesnis ar mažesnis skirtingų manualinès terapijos metodų poveikis gydant nugaros apatinès dalies skausmą.

Tikslas - nustatyti skirtingų manualinès terapijos metodų ir stuburo stabilizavimo pratimų poveikị asmenų, jaučiančių nugaros apatinès dalies skausmą, skausmui ir funkcinei būklei.

Metodai. Buvo tiriama 18 asmenų, jaučiančių lètinį nespecifinị nugaros apatinès dalies skausmą. Atsitiktine tvarka tiriamieji suskirstyti ị dvi grupes. Vienai grupei buvo taikoma stuburo slanksteliu mobilizacija atliekant judesị ir stuburo stabilizavimo pratimai, kitai - nespecifinè stuburo juosmens ir kryžmens manipuliacija bei stuburo stabilizavimo pratimai. Prieš intervenciją ir po jos buvo vertinamas nugaros skausmas, funkcinè būklè ir negalia, pilvo raumenų statinè ištvermè, nugaros raumenų statinè ištvermé, šoninių juosmens raumenų statinè ištvermé, stuburo paslankumas.

Rezultatai. Tiriamujų jaučiamas skausmas po taikytų intervencijų sumažejo $(\mathrm{p}<0,05)$, negalia ir funkcinè būklè pagèrejo $(\mathrm{p}<0,05)$, stuburo paslankumas ir liemens raumenų statinè ištvermé pagerèjo $(\mathrm{p}<0,05)$. Tarp abiejų taikytų metodikų veiksmingumo statistiškai reikšmingo skirtumo nenustatyta.

Išvados. Tiek taikant stuburo slankstelių mobilizaciją atliekant judesị ir stuburo stabilizavimo pratimus, tiek taikant nespecifinę juosmens ir kryžmens manipuliaciją bei stuburo stabilizavimo pratimus, sumažèjo tiriamujų nugaros skausmas ir pagerẻjo funkcinè būklè, poveikis tarp skirtingų manualinès terapijos metodų nesiskyrè.

Raktažodžiai: nugaros apatinès dalies skausmas, stuburo stabilizavimo pratimai, manualinè terapija.

\section{IVADAS}

Apie $85 \%$ populiacijos skundžiasi nespecifiniu nugaros apatinės dalies skaus$\mathrm{mu}$, ir tai yra pagrindinė profesinès veiklos apribojimo priežastis pasaulyje (Trompeter et al., 2017). Labiausiai paplitęs apatinès nugaros dalies skausmo tipas yra nespecifinis, kurio paaiškinimui trūksta aiškios patologinès priežasties (Hussien et al., 2017). Kineziterapeutui pasirinkti tinkamas intervencijas pacientams, jau-

\footnotetext{
Copyright (C) 2020 Šarūnas Zabiela, Rolandas Kesminas, Viljamas Sipavičius. Published by Lithuanian Sports University.

This is an Open Access article distributed under the terms of the Creative Commons Attribution 4.0 International License, which permits unrestricted use, distribution, and reproduction in any medium, provided the original author and source are credited.
} 
čiantiems nugaros apatinès dalies skausmą, yra parengtos tarptautinès įrodymais pagrịstos klinikinès praktikos gairès (Chou, Hoffman, 2017). Visgi gairès bei rekomendacijos, pateiktos skirtingose šalyse, skiriasi ir ne visada atitinka sisteminius apžvalgų rezultatus (Macedo et al., 2016; Chou et al., 2017). Intervencijų rekomendacijos skiriasi ir pagal galimybès, paciento pageidavimus ir jų prieinamumą (Karlsson et al., 2020). Nugaros skausmui gydyti kineziterapeutai siūlo daug intervencijų, iš kurių viena plačiausiai naudojamų yra pratimų terapija (Bernhardsson et al., 2015; Keating et al., 2016).

Nustatyta, kad stuburo stabilizavimo pratimai pagerina juosmens giliụjų raumenų funkciją ir sumažina nugaros skausmą (Ozsoy et al., 2019). Manualinė terapija yra ịprastas terapinis metodas, naudojamas gydant nugaros problemas. Vienoje sisteminèje tyrimų apžvalgoje teigiama, kad yra pakankamai įrodymų apie manualinès terapijos veiksmingumą gydant lètinị apatinès nugaros dalies skausmą (Hidalgo et al., 2014). Kita atlikta sisteminè literatūros apžvalga ir metaanalizė, kurioje buvo tiriama stuburo mobilizacija gydant lètinị nugaros skausmą, parodè, kad neiggalumas ir nugaros skausmas sumažèjo (Coulter et al., 2018). Mulligan'o mobilizacija su judesiu yra plačiai naudojama kineziterapijos ir ortopedinès manualinès terapijos metu bei gali būti taikoma periferiniams ir stuburo sąnariams (Deyo et al., 2009). Ši Mulligan'o stuburo slankstelių mobilizacija atliekant judesį, kai išlaikomas ilgalaikis slydimas tarpslanksteliniame sąnaryje, paprastai naudojama gydant nugaros apatinès dalies skausmą (Seo et al., 2020). Tuo tarpu kiti moksliniai tyrimai rodo, kad papildomai taikant Maitland'o ar Mulligan'o stuburo mobilizavimo metodus simptomų, susijusių su lètiniu nespecifiniu juosmens skausmu, pagerèjimo nebuvo (Ali et al., 2019). Taigi nèra pakankamai tyrimų, kuriuose būtų įrodytas didesnis ar mažesnis skirtingų manualinès terapijos metodų poveikis gydant nugaros apatinès dalies skausmą.

Tyrimo tikslas - nustatyti skirtingų manualinès terapijos metodų ir stuburo stabilizavimo pratimų poveikị asmenų, jaučiančių nugaros apatinès dalies skausmą, skausmui ir funkcinei būklei.

\section{METODAI}

Tiriamieji. Tiriamujjų imtị sudarè 18 moterų, kurios atsitiktinès atrankos būdu buvo suskirstytos ị dvi grupes: 1 grupè $(\mathrm{n}=9)$ - amžius 44,9 $\pm 10,4 \mathrm{~m}$., KMI $25,07 \pm 2,1 ; 2$ grupè $(\mathrm{n}=9)$ - amžius 45,4 $\pm 11,2 \mathrm{~m}$., KMI $-25,37 \pm 3,2$. Tiriamuju atrankos kriterijai: darbingo amžiaus asmenys, jaučiantys nugaros apatinès dalies skausmą ne trumpiau kaip 3 mèn. (lètinis nespecifinis apatinès nugaros dalies skausmas). 


\section{Tyrimo metodai}

Skausmo vertinimas. Nugaros skausmas buvo vertinamas naudojant skaitmeninę analogijos skalę (SAS). Tiriamasis įvertina šiuo metu jaučiamą skausmo intensyvumą skaitmenimis nuo 0 (visiškas skausmo nebuvimas) iki 10 (nepakeliamas skausmas).

Pilvo raumenu statinès ištvermes testas. Tiriamieji atliko Kraus'o-Weber'io testą (Kovacsne et al., 2017). Tiriamasis guli ant nugaros, keliai sulenkti 90 laipsnių kampu, rankos sukryžiuotos ant krūtinès. Tiriamasis lenkia krūtininę dalị, t. y. atkelia mentès apatinị kampą nuo gulimo paviršiaus ir išlaiko kūną statiškai šioje padètyje. Testas yra sustabdomas, jei tiriamasis išlaiko tokią padètị ilgiau kaip 300 s. Testas yra nutraukiamas, kai apatinis mentès kampas nusileidžia ir nebeišsilaiko arba tiriamasis pajaučia nemalonius pojūčius / skausmą.

Nugaros raumenu statinés ištvermès testas. Tiriamieji atliko Ito testą (Müller et al., 2010). Tiriamasis guli ant pilvo, rankos prie šonų delnais ị viršų. Tiriamasis atkelia viršutinę liemens dalị iki apatinès krūtinkaulio dalies nuo gulimo paviršiaus. Testas yra sustabdomas, jei tiriamasis išlaiko tokią padètį ilgiau kaip $300 \mathrm{~s}$. Jei tiriamasis neišlaiko testuojamos padèties ir paliečia pagrindą arba pajaučia nemalonius pojūčius / skausmą, testas taip pat sustabdomas.

Šoniniu liemens raumenu statinès ištvermès testas (McGill et al., 1999). Tiriamieji atliko šoninio tiltelio testą. Tiriamasis guli ant šono, kojos ištiestos, suglaustos vidine dalimi, apačioje esanti ranka dilbiu remiasi ị pagrindą, viršuje - laikoma ant klubo. Tiriamasis remiasi dilbiu ir pédomis, o klubą atkelia taip, kad jis būtu vienoje lygioje linijoje su visu kūnu. Testas stabdomas klubui palietus pagrindą arba tiriamasis pajaučia nemalonius pojūčius / skausmą.

Stuburo paslankumo vertinimas. Stuburo juosmeninès dalies paslankumui vertinti buvo naudojamas Šober'io testas. Jis atliekamas tiriamajam stovint tiesiai, rankos šonuose, tyrëjas tarp klubakaulių skiauterių nugaros pusejje suranda vidurio liniją ir ten pažymi pirmą tašką. $10 \mathrm{~cm}$ aukščiau pirmojo pažymimas antras taškas. $5 \mathrm{~cm}$ žemiau pirmojo pažymimas trečias taškas. Tada tiriamojo prašoma lenktis ị priekị tiek, kiek gali nejausdamas skausmo, nesulenkdamas kelių, ir centimetrine juostele išmatuojamas atstumas tarp pirmo ir trečio taškų. Testas yra neigiamas, kai atstumas tarp pažymètų taškų yra $7 \mathrm{~cm}$ ir didesnis, teigiamas - jei atstumas mažesnis nei $7 \mathrm{~cm}$, ir tai parodo mažą stuburo juosmeninès dalies paslankumą.

Funkcinès büklès ir negalios klausimynas. Nugaros skausmo poveikiui funkcinei būklei ir negaliai vertinti buvo naudojamas Oswestry'io klausimynas (ODI).

Tyrimo organizavimas. Tyrimui atlikti gautas Lietuvos sporto universiteto Bioetikos komiteto leidimas. Tyrimas truko buvo 5 savaitès. Prieš intervenciją buvo vertintas tiriamujų nugaros skausmas, funkcinè būklè ir negalia, stuburo juosmeninès dalies paslankumas, pilvo raumenų statinė ištvermė, nugaros ir šo- 
ninių liemens raumenų statinè ištvermé. Tiriamieji atsitiktine tvarka suskirstyti i dvi grupes.

Pirmą savaitę tiriamiesiems buvo atliktos dvi procedūros: pirmos grupės tiriamiesiems - stuburo sąnariu mobilizacija atliekant judesị ir išlaikant ilgalaikị slydimą tarpslanksteliniame sąnaryje, antros - nespecifinė juosmens ir kryžmens manipuliacija.

Kitas 4 savaites (3 kartus per savaitę po $60 \mathrm{~min}$ ) visiems tiriamiesiems buvo taikoma kineziterapija, nukreipta ị juosmens giliujų raumenų stiprinimą ir stuburo stabilizavimą. Kiekviena procedūra buvo suskirstyta ị tris dalis: pramankštą (10 min), pagrindinę treniruotès dalį (45 min) ir atsipalaidavimą (5 min). Pratimai atliekami iš įvairių padèčiu (klūpint ant kelių, keturpèsčia, gulint ant pilvo / nugaros, stovint). Pirmujų kineziterapijos procedūrų metu tiriamieji buvo mokomi surasti neutralią juosmeninès stuburo dalies padèti, pajusti dubens judesius. Visų procedūrų metu daug dèmesio buvo skiriama dubens dugno ir pilvo bei nugaros raumenų stiprinimui, juosmeninès stuburo dalies stabilizavimui, judesių koordinacijos gerinimui.

\section{Intervencijos}

Stuburo mobilizacija atliekant judesi (I grupei). Ji yra vadinama SNAG (SNAG - angl. Sustained Natural Aphophyseal Glide). Tai neskausmingas manualinis sąnarinio paviršiaus pastūmimas specifine jèga pagal sąnarinių ataugų plokštumą ir išlaikymas viso prieš tai skausmingo judesio metu. SNAG atliekama toje vietoje kur veiksmingiausiai sumažina skausmą ir padidina neskausmingo judesio amplitudę. SNAG buvo naudojama vieno bet kurio skausmingo arba skausmingiausio judesio metu. Skausmingi judesiai nustatomi atlikus anamnezę ir įvertinus aktyvius liemens judesius. Atlikus SNAG 3 serijas po $10 \mathrm{k}$., pacientas atliko 1 seriją 10 dubens / liemens lenkimo / tiesimo judesių (pratimas Katè).

Nespecifine juosmens ir kryžmens manipuliacija (II grupei). Pacientas atsigula ant nugaros ir suima rankas už galvos. Terapeutas, stovėdamas neskausmingoje paciento puseje, patraukia dubenị arčiau savęs, toliau atlieka liemens pasukimą link savęs ir šoninị lenkimą nuo savęs. Didelio greičio, mažos amplitudės impulsu paspaudžiamas klubakaulis ties priekiniu viršutiniu klubakaulio dygliu posteriorine ir šiek tiek inferiorine kryptimi. Jei buvo išgaunamas kavitacijos garsas manipuliuojant, pereinama prie liemens mobilumo pratimo Kate (angl. Cat and Camel). Jei garsas nebuvo išgaunamas, pacientas užima pradinę padėtị iš naujo, ir manipuliacija kartojama. Jei ir vèl kavitacija neišgaunama, manipuliuojama kita pusè. Daugiausia buvo atliekamos dvi kiekvienos pusès manipuliacijos.

Matematinè statistika. Tyrimo duomenys buvo analizuojami naudojant Statistics 17.0 bei Microsoft Excel 2016 statistinių programų paketus. Kiekybiniams kintamiesiems vertinti buvo apskaičiuoti aritmetiniai vidurkiai ir jų standartiniai 
nuokrypiai (SN). Duomenų pasiskirstymui pagal normaluji skirstini patikrinti buvo naudojamas Shapir'o-Wilk'o testas. Statistinis duomenų, kurie pasiskirstę pagal normalujji skirstinị, reikšmingumas buvo skaičiuojamas pagal Student'o $t$ kriterijų, o nepasiskirsčiusių - pagal normalųji skirstinį ir pagal Wilcoxon'o kriterijų. Skirtumas statistiškai reikšmingas, jeigu gautoji $p$ reikšmė yra mažesnė už reikšmingumo lygmenį, t. y. jeigu $\mathrm{p}<0,05$.

\section{TYRIMO REZULTATAI}

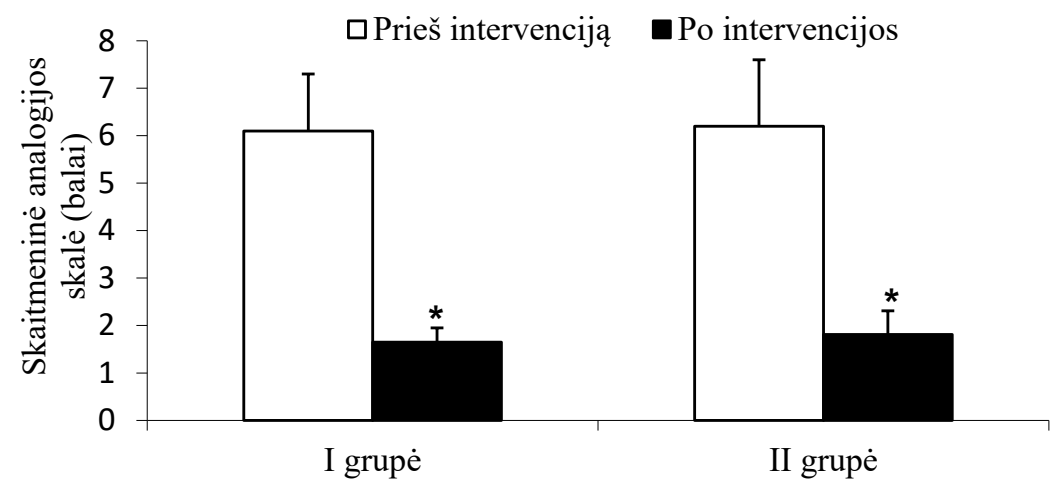

Pastaba. ${ }^{*}-\mathrm{p}<0,05$, lyginant rodiklius prieš intervenciją ir po jos.

1 pav. Tiriamųjų apatinès nugaros dalies skausmas prieš intervenciją ir po jos

Po intervencijos statistiškai reikšmingai $(\mathrm{p}<0,05)$ sumažejo tiriamujų nugaros skausmas abiejose grupėse: I grupeje - 72,95\%, II - 70,97\% (1 pav.).

Po intervencijos padidèjo $(\mathrm{p}<0,05)$ juosmeninès stuburo dalies paslankumas abiejose grupèse: I grupeje - 51,6\%, II - 47,3\% (2 pav.).

Po intervencijos statistiškai reikšmingai abiejose grupèse padidejo pilvo ir nugaros raumenų statinè ištvermè: I grupeje pilvo - 33,2\%, nugaros - $34,4 \%$; II grupeje pilvo $-32,7 \%$, nugaros $-37,8 \%$ (3 pav.).

Po intervencijos padidèjo $(\mathrm{p}<0,05)$ šoninių liemens raumenų statinè ištvermé abiejose grupèse: I grupejje kairèje puseje $51,4 \%$, dešinèje - 42,7\%; II grupejje kairèje pusèje $-41,7 \%$, dešinèje $-38,3 \%$ (4 pav.).

Po intervencijos statistiškai reikšmingai $(\mathrm{p}<0,05)$ sumažejo negalia ir pagerejjo funkcinè būklè abiejose grupèse: I grupèje $-48,18 \%$, II - 46,39\%. Tarp grupių vertinant funkcinè būklès ir negalios rodiklius, statistiškai reikšmingo skirtumo nei prieš intervenciją, nei po jos nebuvo nustatyta (5 pav.). 


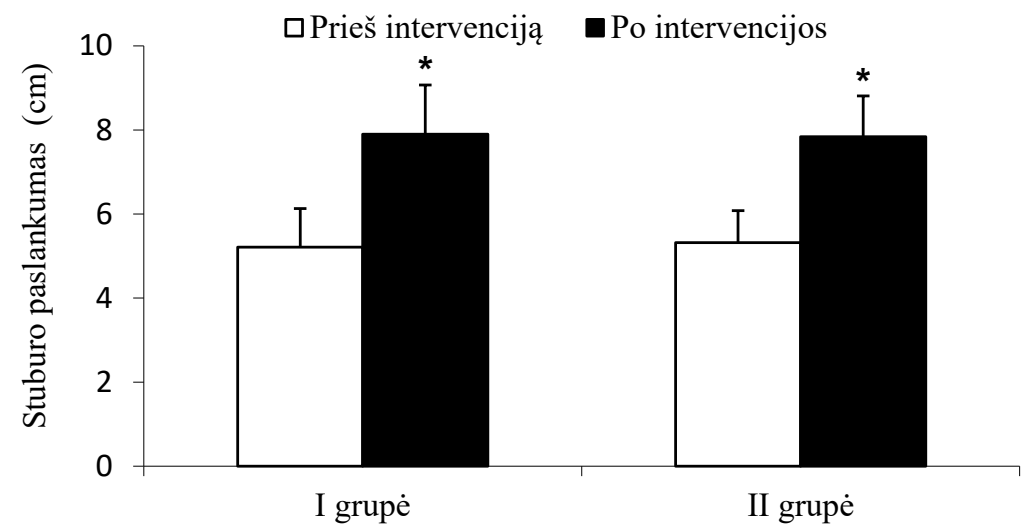

Pastaba. * $-\mathrm{p}<0,05$, lyginant rodiklius prieš intervenciją ir po jos.

2 pav. Tiriamųjų juosmeninès stuburo dalies paslankumas prieš intervenciją ir po jos

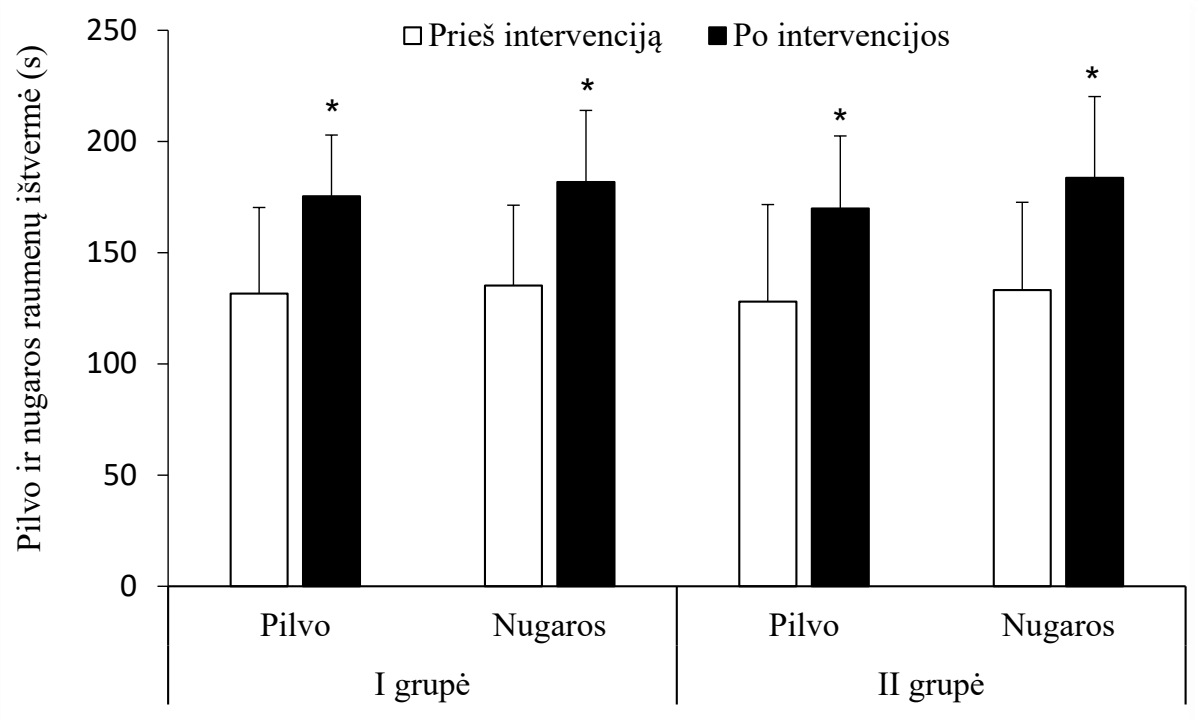

Pastaba. * $-\mathrm{p}<0,05$, lyginant rodiklius prieš intervenciją ir po jos.

3 pav. Tiriamųjų pilvo ir nugaros raumenų statinė

ištvermė prieš intervenciją ir po jos 


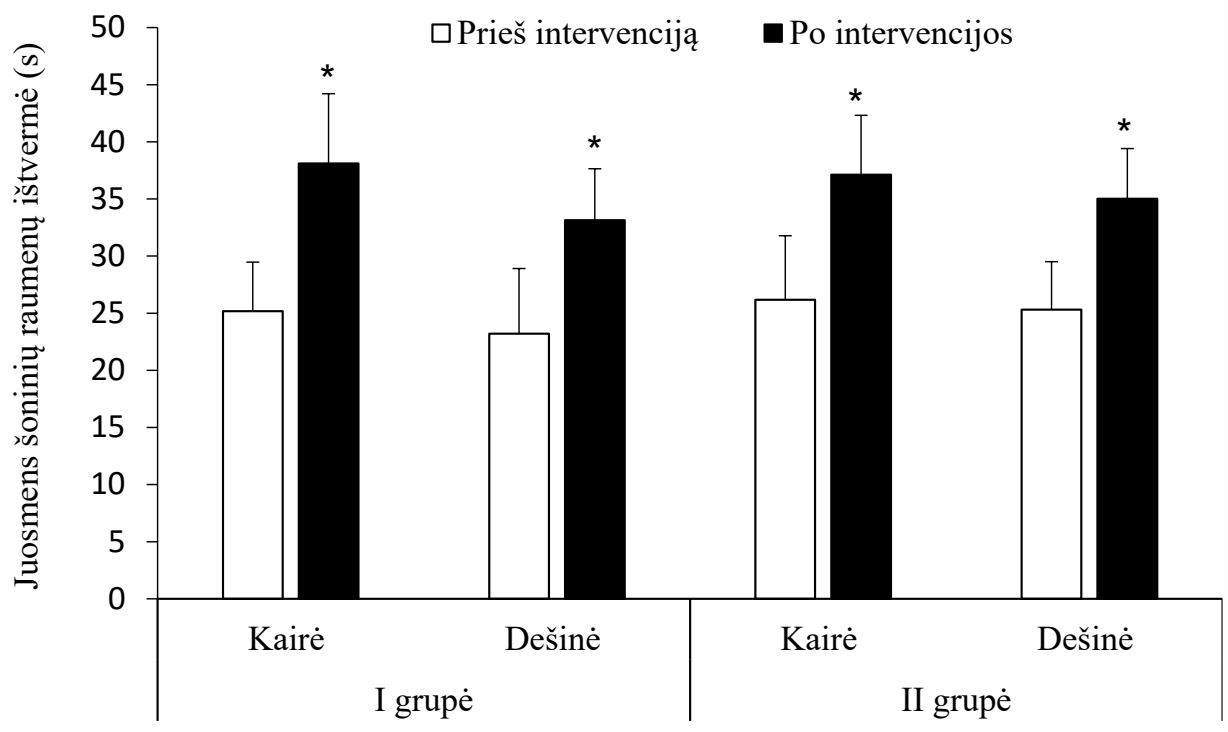

Pastaba. ${ }^{*}-\mathrm{p}<0,05$, lyginant rodiklius prieš intervenciją ir po jos.

4 pav. Tiriamųjų šoninių liemens raumenų statinė ištvermė prieš intervenciją ir po jos

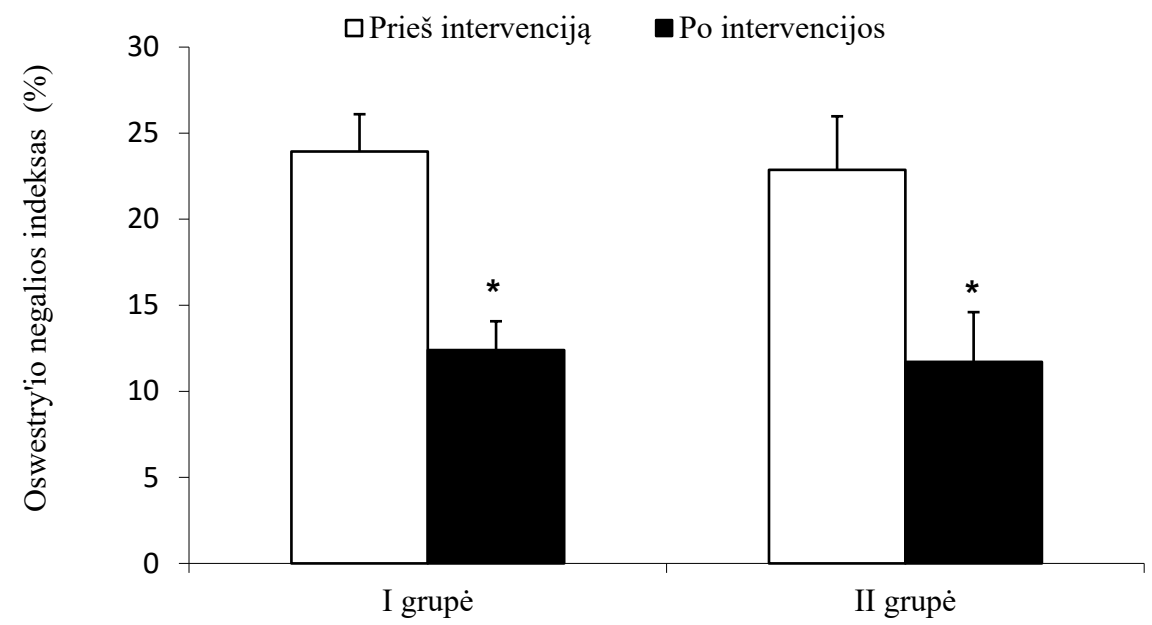

Pastaba. * $-p<0,05$, lyginant rodiklius prieš intervenciją ir po jos.

5 pav. Tiriamụjų funkcinė būklè ir negalia prieš intervenciją ir po jos 


\section{REZULTATŲ APTARIMAS}

Mūsų tyrimo rezultatai parodè, kad taikant stuburo slankstelių mobilizaciją atliekant judesį arba taikant nespecifinès stuburo juosmens ir kryžmens manipuliaciją ir stuburo stabilizavimo pratimus sumažeja skausmas ir negalia, pagerejja asmenų, jaučiančių nespecifinị lètinị nugaros apatinès dalies skausmą, funkcinè būklè bei juosmens raumenų statinè ištvermè ir stuburo paslankumas.

Šiame tyrime buvo taikomi nugaros apatinès dalies skausmo mažinimo ir funkcinès būklès gerinimo stuburo stabilizavimo pratimai. Mūsų tyrimo rezultatai parodè teigiamą poveiki pilvo ir nugaros raumenų statinei ištvermei, stuburo juosmens paslankumui ir skausmo valdymui. Mokslininkai atliko stuburo stabilizavimo pratimų veiksmingumo tyrimų apžvalgą, kuri parodè akivaizdų asmenų, jaučiančių nespecifinị juosmens skausmą, skausmo intensyvumo sumažèjimą (Luomajoki et al., 2018).

Moksliniuose straipsniuose pateikiama keletas įrodymų, kad stuburo stabilizavimo ir liemens raumenų ištvermès pratimai yra naudingi asmenims, jaučiantiems lètinius apatinès nugaros dalies skausmus (Shamsi et al., 2017), ir specifiniai stabilizavimo pratimai gali būti veiksmingesni nei kitų rūšių pratimai gerinant nugaros specifinę funkcinę būklę (Gomes-Neto et al., 2017), o stuburo stabilizavimo pratimų programa pagerina liemens giliụjų raumenų funkciją ir sumažina nugaros skausmą (Ozsoy et al., 2019).

Kineziterapijos praktikoje ịprastai naudojamos ịvairios manualinès terapijos, tokios kaip pasyvi Maitland'o mobilizacija, manipuliacija ir Mulligan'o mobilizacija atliekant judesị (Hussien et al., 2017). Muligan'o mobilizavimo technika pagerina sąnario judrumą taikant ilgalaikį pasyvų slydimą ant stuburo juosmeninès dalies tarslankstelinių sąnarių (SNAG), kai tiriamasis tuo pačiu metu atlieka aktyvų judesi, paprastai naudojamą gydant nugaros apatinės dalies skausmą (Seo et al., 2020). Moksliniuose straipsniuose nurodoma, kad Muligan'o mobilizavimo technika SNAG gali greitai numalšinti nugaros skausmą ir pagerinti judesio diapazoną, nes tai ištaiso facetinio sąnario klaidingą padètị (Hing et al., 2015; Hussien et al., 2017). Neseniai atlikto tyrimo rezultatai rodo, kad sumažèjo skausmas ir pagerèjo funkcinè negalia tiek kontrolinès, tiek Mulligan'o stuburo mobilizavimo metodo SNAG paveiktoje grupeje, tačiau SNAG grupèje nustatytas didesnis pagerejjimas. Taigi, remiantis šiais rezultatais, juosmens SNAG ịtraukimas ị ịprastą apatinès nugaros dalies funkcijos gerinimo programą gali padèti gauti palankesnių rezultatų vertinant skausmą ir funkcinę negalią (Hussien et al., 2017). Atliktas tyrimas norint palyginti Mulligan'o stuburo mobilizavimo metodą SNAG ir Mckenzie'io pratimų poveikị parodè, kad SNAG veiksmingiau gydè pacientus, kuriems nustatytas lètinis mechaninis apatinès nugaros dalies skausmas (Waqqar et al., 2016). 
Atlikus Mulligan'o stuburo mobilizavimą SNAG metodu, pagerejo pacientų, kurie jautè mechaninį apatinès nugaros dalies skausmą nepriklausomai nuo to, ar jie atliko laikysenos korekcijos pratimus, ar ne, funkcinè būklè ir judesio amplitudè, sumažèjo nugaros skausmas (Ain et al., 2019).

Mūsų tyrimo rezultatai parodè, kad taikant stuburo slankstelių mobilizaciją atliekant judesị, kai išlaikomas ilgalaikis slydimas tarpslanksteliniame sąnaryje, reikšmingai sumažèjo asmenų, jaučiančių nespecifinị lètinị nugaros apatinès dalies skausmą, skausmas ir negalia, pagerèjo funkcinè būklè ir stuburo juosmeninès dalies paslankumas. Taigi galima teigti, kad mūsų tyrimo rezultatai neprieštarauja anksčiau minètiems mokslininkų darbams, kurie teigia, kad Mulligan'o stuburo mobilizavimas SNAG metodu teigiamai veikia nugaros skausmo gydymą ir negalios mažinimą. Pridèjus SNAG prie ịprastų kineziterapijos programų gydant lètinị nespecifini nugaros apatinès dalies skausmą, galima labiau sumažinti skausmą ir pagerinti funkciją (Hussien et al., 2017).

Mūsų tyrime taip pat buvo taikoma nespecifinès stuburo juosmens ir kryžmens srities manipuliacija, ir buvo gautas teigiamas poveikis. Taikant vienkartinę nespecifinę stuburo juosmens ir kryžmens manipuliaciją asmenimis, jaučiantiems ne radikulopatinị nugaros apatinès dalies skausmą, gydymas gali būti sẻkmingas maždaug 45\% atvejų (Flynn et al., 2002). Anksčiau atliktų tyrimų rezultatai tai patvirtina, todèl pacientams, jaučiantiems apatinès nugaros dalies skausmą, gali būti labai naudinga atlikti nespecifinę stuburo juosmens ir kryžmens manipuliaciją (Childs et al., 2004; Cleland et al., 2009).

Šiuo tyrimu buvo siekiama ịvertinti dviejų skirtingų manualinès terapijos metodụ poveikị asmenų, jaučiančių nespecifinị lètinị nugaros apatinès dalies skausmą, skausmui ir funkcinei būklei. Mūsų tyrimo rezultatai parodè, kad abiejų manualinès terapijos metodų poveikis nugaros apatinės dalies skausmui ir negaliai, stuburo juosmeninès dalies paslankumui bei funkcinei būklei buvo panašus ir statistiškai reikšmingai nesiskyrè. Galima svarstyti, kad tyrimo rezultatams galëjo turèti įtakos maža tiriamujų imtis, taigi reikètų išsamesnių tyrimų. Neseniai atlikto tyrimo tikslas buvo palyginti Maitland'o stuburo mobilizavimo ir Mulligan'o stuburo mobilizavimo SNAG metodu poveikị asmenų, sergančių lètiniu nespecifiniu nugaros apatinès dalies skausmu, skausmui, judrumui, raumenu aktyvacijai ir funkcinei negaliai, ir buvo padaryta išvada, kad abiejų šių manualinès terapijos metodų poveikis yra panašus (Ali et al., 2019).

Remiantis mūsų tyrimo rezultatais galima teigti, kad gydant nespecifinị lètinị nugaros apatinès dalies skausmą yra veiksminga taikyti tiek stuburo slankstelių manipuliaciją atliekant judesį, tiek nespecifinę stuburo juosmens ir kryžmens manipuliaciją kartu su stuburo stabilizavimo pratimais dẻl teigiamo poveikio juos- 
mens raumenų statinės ištvermès ir stuburo juosmeninès dalies paslankumo didinimui, skausmo ir negalios mažinimui bei funkcinès būklès gerinimui.

\section{IŠVADA}

Tiek taikant stuburo slankstelių mobilizaciją atliekant judesį ir stuburo stabilizavimo pratimus, tiek taikant nespecifinę stuburo juosmens ir kryžmens manipuliaciją bei stuburo stabilizavimo pratimus, sumažèjo nugaros apatinès dalies skausmas ir pagerèjo tiriamųjų funkcinè būklè. Poveikis tarp skirtingų manualinès terapijos metodų nesiskyrè.

\section{Finansavimas: nèra.}

Interesų atskleidimas: nèra.

\section{LITERATŪRA}

Ain, T. S. Q., Rehman, U. S. S., Maryam, M., Kiani, S. K. (2019). Effects of Sustained Natural Apophyseal Glides with and without thoracic posture correction techniques on mechanical back pain: A randomized control trial. Pakistan Medical Association, 69, 1584-1587.

Ali, M. N., Sethi, K., Noohu, M. M. (2019). Comparison of two mobilization techniques in management of chronic non-specific low back pain. Journal of Bodywork and Movement Therapies, 23, 918-923.

Bernhardsson, S., Oberg, B., Johansson, K., Nilsen, P., Larsson, M. E. (2015). Clinical practice in line with evidence? A survey among primary care physiotherapists in western Sweden. Journal of Evaluation Clinical Practice, 21, 1169-1177.

Childs, M. J. D., Fritz, J. M., Flynn, T. W. et al. (2004). A clinical prediction rule to identify patients with low back pain most likely to benefit from spinal manipulation: A validation study. Annals of Internal Medicine, 141, 920-928.

Chou, R., Deyo, R., Friedly, J. et al. (2017). Nonpharmacologic therapies for low back pain: A systematic review for an American College of Physicians Clinical Practice Guideline. Annals of Internal Medicine, 166, 493505 .

Chou, R., Hoffman, L. H. (2017). Guideline for the evaluation and management of low back pain-evidence review. American Pain Society.

Cleland, J. A., Fritz, J. M., Kulig, K., Davenport, T. E., Childs, J. D. (2009). Comparison of the effectiveness of three manual physical therapy techniques in a subgroup of patients with low back pain who satisfy a clinical prediction rule. Spine, 34, 2720-2729.

Coulter, I. D., Crawford, C., Hurwitz, E. L. et al. (2018). Manipulation and mobilization for treating chronic low back pain: A systematic review and meta-analysis. The Spine Journal,18, 866-879.

Deyo, R. A., Mirza, S. K., Turner, J. A., Martin, B. I. (2009). Overtreating chronic back pain: Time to back off? Journal of the American Board of Family Medicine 22, 62-68.

Flynn, T., Fritz, J., Whitman, J., Wainner, R., Allison, S. (2002). A clinical prediction rule for classifying patients with low back pain who demonstrate short-term improvement with spinal manipulation. Spine, 27, 28352843.

Gomes-Neto, M., Lopes, J. M., Conceicao, C. S. et al. (2017). Stabilization exercise compared to general exercises or manual therapy for the management of low back pain: A systematic review and meta-analysis. Physical Therapy in Sport, 23, 136-142.

Hidalgo, B., Detrembleur, C., Hall, T., Mahaudens, P., Nielens, H. (2014). The efficacy of manual therapy and exercise for different stages of non-specific low back pain: An update of systematic reviews. The Journal of Manual Manipulative Therapy, 22, 59-74. 
Hing, W., Hall, T., Rivett, D. A., Vicenzino, B., Mulligan, B. (2015). The Mulligan Concept of Manual TherapyeBook: Textbook of Techniques. Elsevier Health Sciences.

Hussien, H. M., Abdel-Raoof, N. A., Kattabei, O. M., Ahmed, H. H. (2017). Effect of Mulligan Concept Lumbar SNAG on chronic nonspecific low back pain. Journal of Chiropractic Medicine, 16, 94-102.

Karlsson, M., Bergenheim, A., Larsson, M. E. H., Nordeman, L., Bernhardsson, M. (2020). Effects of exercise therapy in patients with acute low back pain: A systematic review of systematic reviews. Systematic Reviews, $14,182$.

Keating, J. L., McKenzie, J. E., O’Connor, D. A. et al. (2016). Providing services for acute low-back pain: A survey of Australian physiotherapists. Manual Therapy, 22, 145-152.

Kovácsné Bobály, V., Szilágyi, B., Makai, A., Koller, Á., Járomi, M. (2017). Improvement of lumbar motor control and trunk muscle conditions with a novel low back pain prevention exercise program. Orvosi Hetilap, $158,58-66$.

Luomajoki, H. A., Beltran, M. B., Careddu, S., Bauer, C. M. (2018). Effectiveness of movement control exercise on patients with non-specific low back pain and movement control impairment: A systematic review and meta-analysis. Musculoskeletal Science and Practice, 36, 1-11.

Macedo, L. G., Saragiotto, B. T., Yamato, T. P. et al. (2016). Motor control exercise for acute non-specific low back pain: A Cochrane review. Spine Affiliated Society Meeting Abstracts, 15, 1284-1295.

McGill, S. M., Childs, A., Liebenson, C. (1999). Endurance times for low back stabilization exercises: clinical targets for testing and training from a normal database. Archives of Physical Medicine and Rehabilitation, 80 (8), 941-944.

Müller, R., Strässle, K., Wirth, B. (2010). Isometric back muscle endurance: An EMG study on the criterion validity of the Ito test. Journal of Electromyography and Kinesiology, 20, 845-850.

Ozsoy, G., Ilcin, N., Ozsoy, I. et al. (2019). The effects of myofascial release technique combined with core stabilization exercise in elderly with non-specific low back pain: A randomized controlled, single-blind study. Aging, 14, 1729-1740.

Seo, U. H., Kim, J. H., Lee, B. H. (2020). Effects of Mulligan Mobilization and Low-Level Laser Therapy on physical disability, pain, and range of motion in patients with chronic low back pain: A pilot randomized controlled trial. Healthcare, 8, 237.

Shamsi, M., Sarrafzadeh, J., Jamshidi, A. (2017). Comparison of spinal stability following motor control and general exercises in nonspecific chronic low back pain patients. Clinical Biomechanics, 48, 42-48.

Trompeter, K., Fett, D., Platen, P. (2017). Prevalence of back pain in sports: A systematic review of the literature. Sports Medicine, 47, 1183-1207.

Waqqar, S., Shakil-ur-Rehman, S., Ahmad, S. (2016). McKenzie treatment versus mulligan sustained natural apophyseal glides for chronic mechanical low back pain. Pakistan Journal of Medical Sciences, 32, 476-479.

\title{
EFFECTS OF MANUAL THERAPY AND EXERCISES ON BACK PAIN AND FUNCTIONAL STATUS
}

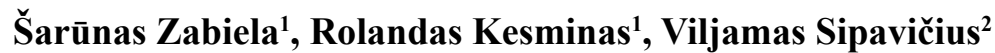 \\ Lithuanian Sports University ${ }^{l}$ \\ Lithuanian University of Health Sciences ${ }^{2}$
}

\section{ABSTRACT}

Background. Studies have found that spinal stabilization exercises improve lumbar deep muscle function and reduce back pain. Spinal mobilization and manipulation reduce disability and pain in the treatment of chronic back pain. However, 
there are not enough studies to show a greater or lesser effect of different manual therapies in the treatment of lower back pain.

Aim. Research aim was to determine the effect of different manual therapy methods and spinal stabilization exercises on pain and functional status in individuals experiencing lower back pain.

Methods. The study included 18 subjects experiencing chronic nonspecific lower back pain. The subjects were randomly divided into two groups. One group underwent spinal vertebral mobilization with movement (sustained natural apophyseal glides - SNAG's) and spinal stabilization exercises, and the other group underwent non-specific lumbar spine manipulation and spinal stabilization exercises. Before and after the intervention back pain (SAS), functional status and disability, abdominal muscle static endurance, back muscle static endurance, lateral trunk muscle static endurance, and spine mobility were assessed.

Results. All subjects had statistically significant $(\mathrm{p}<0.05)$ changes in results related with pain, disability and functional status, lumbar spine mobility, and lumbar muscle static endurance, comparing them before and after the intervention. The results of the study before and after the intervention did not differ significantly between the groups.

Conclusion. Spine mobilization with movement and core stability exercises as well as non-specific lumbar-sacral spine manipulation and core stability exercises were found to reduce low back pain and improve functional status; the effects did not differ between different manual therapy methods.

Keywords: low back pain, spinal stabilization exercises, manual therapy.

Gautas 20201110

Priimtas 20201221 